\title{
Printed Pages, Perfect Souls? Ideals and Instructions for the Devout Home in the First Books Printed in Dutch
}

\author{
Anna Dlabačová \\ Leiden University Center for the Arts in Society (LUCAS), Leiden University, P.N. van Eyckhof 1, \\ 2300 RA Leiden, The Netherlands; a.dlabacova@hum.leidenuniv.nl
}

Received: 6 December 2019; Accepted: 9 January 2020; Published: 16 January 2020

\begin{abstract}
This article studies the role of the earliest books printed in the Dutch vernacular in the religious practice of lay individuals and the devout home. Many of the texts disseminated in these early printed books have received little attention and scholars have tended to view them within the sphere of the Modern Devotion, even though often there is no direct link to this religious reform movement. This article attempts to show that the first books printed in Dutch offer an interesting lens through which to study domestic devotion in the Low Countries in the last decades of the fifteenth century. It argues that these books bridged the gap between catechetical instruction and the private home, literally bringing home many of the ideals and instructions that the clergy would have offered in church and thus increasingly 'textualizing' the lives of the late medieval laity. Printers such as Gerard Leeu and his contemporaries acquainted Christians to the use of printed books for personal and practical religious instruction and knowledge and thus paved the way for developments in the sixteenth century.
\end{abstract}

Keywords: Dutch medieval literature; devotional literature; catechesis; religious instruction; lay devotion; incunabula; Gerard Leeu; manuscript and print; Dionysius the Carthusian; Der grosse Seelentrost

\section{Introduction}

With regard to devotion and religion, the impact of the early printing press is still often associated with the Protestant Reformation (Wandel 2016, p. 18; Pettegree 2015; Füssel 2003, pp. 159-93). Recently, Lee Palmer Wandel claimed that until the sixteenth century, knowledge of Christianity was mainly mediated through things, experiences and acts (Wandel 2016, pp. 9-14). For the majority of Christians the Lord's Prayer, the Apostle's Creed, the Ten Commandments, and so on, "were not ink on a page", but sounds. Moreover, "no one claimed a 'catechism' [ ... ] contained all that a Christian ought to know" (Wandel 2016, p. 11). The importance of the printed book during the Reformation cannot be denied. But while 'catechism' is a sixteenth-century word, Michael Milway has noted that sixteenth-century catechisms differ from their late medieval predecessors in style rather than contents (Milway 2000, p. 128, n. 51). Yet relatively little attention has been paid to the many printed books and booklets published in the Dutch vernacular before the start of the sixteenth century that were not pastoralia — works primarily intended to instruct the clergy (see Milway 2000, pp. 126-30). Rather, the works under discussion here instruct lay readers on how to live a pious life and offer both basic and more advanced religious knowledge, even teaching "what every Christian should know" (cf. Wandel 2016, pp. 15 and 22) ${ }^{1}$.

1 On the function and (intended) audience of Middle Dutch catechetical texts and works on moral theology, see (Warnar 1993, pp. 44-49). 
These books are still largely uncharted territory. The only two monographs that discuss a wide range of texts from the Low Countries that can be characterized-in a teleological way-as pre-Reformation catechisms date back to the first years of the twentieth century and were written from a Protestant point of view (Troelstra 1901 and Troelstra 1903). In a 1993 article, Geert Warnar focused on catechesis and "moral theology" for lay men, which resulted from the Fourth Lateran Council of 1215. Warnar discussed predominantly works transmitted in manuscript and indicated that Middle Dutch catechetical texts (from the fourteenth century onward) were intended to function independently from institutional catechetical instruction (Warnar 1993, pp. 48-49). They were mainly aimed at use within the private sphere of the household, especially in the education of youngsters. He characterized these works for a domestic setting as textualized forms of sermons and catechesis. Petty Bange's work on "the moralistic discourse" in the late medieval Low Countries, has brought together an anthology of useful information about moral instruction for lay people in Middle Dutch, both in manuscript and in print (Bange 2007). Bange, however, only included texts available in a modern edition, which significantly narrowed down her corpus, especially with regard to the many devotional texts that appeared in print ${ }^{2}$.

Herman Pleij ascribed the early printed religious literature in Dutch to a dominant role of the clergy, both on the side of production and consumption, and a demand for spiritual self-help fanned up by the religious reform movement of the Modern Devotion (Pleij 1992a, pp. 12-19; Pleij 1992b, pp. 235-44; Pleij 2010, p. 290; Warnar 1993, p. 50) ${ }^{3}$. Pleij deplores the lack of research into printed (religious) works and the role of the clergy, but nevertheless proceeds to posit that the early printing press in the Northern Netherlands was never commercial. According to Pleij commercialization only took off once printers moved south (to Antwerp) where the clergy ceased to be significant (Pleij 1992b, pp. 245 and 248; Pleij 2010, pp. 290-91). Koen Goudriaan problematizes this supposed opposition between North and South (Goudriaan 1992, pp. 203-5). Moreover, while often viewed almost exclusively as the birth-region of the Modern Devotion, religious life and literature in the Low Countries was, perhaps not surprisingly, influenced by various other religious orders and reform movements during the fifteenth century. The influence of the Devotio Moderna with regard to the introduction of the printed book has also been overestimated (Goudriaan 2013a, pp. 582-91).

Although the Modern Devotion stimulated the use of texts as the main tool for spirituality (e.g., Mertens 1993), Goudriaan has convincingly argued that the involvement of the Devotio Moderna in the production of printed books was limited (Goudriaan 2013a). In the fifteenth century, only three religious houses connected to the Modern Devotion and located in the Low Countries ran a printing press-in Brussels, Gouda, and Schoonhoven (near Gouda). Their reason for existence, however, was never the provision of vernacular books to lay people-rather, their core business appears to have been liturgical texts. Sometimes they tapped into popular devotional trends, but their production was subject to commercial laws of supply and demand (Goudriaan 2013a; Goudriaan 2010 on the press of the Gouda Collaciebroeders; Kock 2002), as with the business of secular printers. Secular, commercially operating printers collaborated with members of the secular and regular clergy. Again, the main suppliers of religious and devotional texts to these shops were not the Modern Devout, but the reformed Franciscans (Franciscan Observants)—-the Carthusians came in second place (Goudriaan 2013b, 2016, pp. 280-81). The Church, however, did not adopt a single, centralized strategy towards the new medium. Vernacular devotional books that came on the market were primarily produced by commercially operating printing shops and met a demand for catechetical and devotional texts among the laity ${ }^{4}$.

2 See also her earlier work on the (rather disparate) genre of 'Mirrors': (Bange 1986).

3 Warnar states that the first printers likely thought that Middle Dutch catechetical literature would ensure sales. He also emphasizes the diversity of these kinds of texts, which shows that the various needs of lay people were addressed. Cf. (Mertens 1993, p. 13 and n. 15).

4 A similar situation occurred in Lübeck: (Andersen 2016). 
The focus of the present article is solely on incunabula (books printed before 1501) and offers an incomplete overview of religious instruction in the late fifteenth century household as illuminated by these sources ${ }^{5}$. My aim is to provide a number of examples of texts that early printers made available for the laity and the lay home and, as such, to point to their potential as sources for research into domestic devotion. The first books printed in the Dutch vernacular offer an interesting lens for the study of domestic devotion in the Low Countries in the last decades of the fifteenth century: even though the books themselves (and the surviving copies) are often the only evidence of their role in domestic devotion, the very fact they were printed implies that they met a certain demand amongst lay readership. What did the ideal pious household look like according to Dutch incunabula? In what way did they aim to instruct lay audiences? The discussion of this small sample of texts shows that the supposed caesura between the fifteenth and sixteenth centuries as ages of respectively experientially and textually-through the printed book-oriented knowledge-transfer is not tenable. The situation in the last quarter of the fifteenth century was more complicated and the present essay hopes to invite further research into the role of commercially produced incunabula in the religious practice of lay people.

In order to meet the ideals and practical instructions given in the printed books discussed below, readers would often need (other) textual materials such as prayer collections, Books of Hours or meditative texts. While my primary focus in this essay is on the former (ideals and instructions), if we are to better understand the role of the religious printed books in lay households, the latter should not be ignored. Printed books with both kinds of texts would often have functioned as objects of domestic devotion, alongside manuscripts. Recent studies, notably by Sabrina Corbellini and Margriet Hoogvliet on the appropriation of religious texts by artisans, have pointed to lay ownership of religious works in France and Italy (Corbellini and Hoogvliet 2013). The texts one would need to live up to the ideals and/or to follow the given instructions could be directly supplemented in the very same book, or readers could find them in other (more specialized) editions. The Ten Commandments, discussed in the first section of the present essay, could be found briefly listed in the Tafel des kersteliken levens (Table of Christian Life), elaborately discussed and supplemented with exempla and prayers in the Der sielen troest (The Soul's Consolation), and yet, as we will see, to comply fully, for instance, with the third commandment (keep holy days), one might also need a Book of Hours, a treatise with an explanation of the Mass and/or a meditative life of Christ. All of these texts became readily available in print through the activity of commercial entrepreneurs.

One of the most popular and voluminous catechetical texts in late medieval printing shops of the Low Countries was originally not written in Dutch or in Latin, but in Low German. The Soul's Consolation was composed around 1350 (the oldest manuscript dates from 1403), possibly by a member of the Dominican order (Schmitt 1959; Palmer 1992, cols. 1030-40; Warnar 1993, pp. 46-47). The extant manuscript transmission of the Dutch translation of The Soul's Consolation is modest: only three manuscripts contain the full Dutch text (Deschamps 1963, 1972, pp. 193-97). The commitment to private lay devotion to which The Soul's Consolation testifies took wings with the first printed edition in the Netherlands, published as early as 1478 . The Dutch text remained in print until 1800, which attests to a remarkable longevity of this work and continuity in religious instruction (Schmitt 1959, pp. 32-34, p. 117; Murjanoff 1964, pp. 206-9). Margarete Schmitt, the editor of the modern edition of the Middle Low German text, tried to relate the dissemination of The Soul's Consolation, and in particular the popularity of the Dutch translation in print, to the Modern Devotion. More recent insights into the lack of involvement of the Modern Devotion in printing—as discussed above—show that it is highly unlikely that the Modern Devout were responsible for the editions (Schmitt 1959, pp. 141-42) ${ }^{6}$. Rather,

5 The references to incunabula include the ISTC number, which refers to the (ISTC database).

6 Schmitt situates the entire text within the sphere of influence of the Modern Devotion. However, since the text predates the movement, it cannot be connected directly to the Modern Devotion. Schmitt next tries to make a case for a strong involvement of the Modern Devotion within the text's dissemination. 
the venture was a commercial one. I use this text and the ways it encourages readers to put the Ten Commandments into practice in their daily lives as a starting point for an exploration of domestic devotion in Dutch incunabula. I then elaborate on two central themes that can be distilled from the The Soul's Consolation: prayer and meditation, and family life within a religious household.

\section{Bringing the Ten Commandments Home}

The anonymous fourteenth-century author of The Soul's Consolation collected over 200 exempla. Hence, the text is often presented as an exempla-collection (Deschamps 1972, p. 193: the work consists "almost entirely out of stories and exempla [ ... ]"), but the frame story written per modum dyalogi is at least equally important. Although often overlooked, the dialogue between a father (confessor) and a flexible-gendered child about the Ten Commandments is the most original part of the text, and it organizes and interprets the exempla taken from a variety of sources, including the Bible, Jacobus de Voragine's Legenda aurea, Petrus Comestor's Historia Scholastica, the Gesta Romanorum and many others. It is in the dialogic parts of the text that the father explicitly answers the child's casuistic questions, explains the different ways in which the Commandments can be understood and gives direct instructions on matters of faith and domestic devotion, which is our particular concern here (cf. Palmer 1992, col. 1033).

The first commandment is introduced as "how one should love God" (hoemen god minnen sal) in the rubric. At the start of the chapter, the reader is addressed as follows: "O man, you shall not honor idols or alien gods" (O mensche, $d u$ en selste gheen afgoden of vremde goden aenbeden) ((Der sielen troest 1484, a3r-v; Schmitt 1959, p. 5, 11. 1-9) ${ }^{7}$. The father repeatedly warns against any belief in superstition and instructs the child not to keep any books on magic in his possession (Der sielen troest 1484, b1r; Schmitt 1959, p. 18). He supports his teaching with a story about a woman who believed in spirits, that takes on a particularly domestic form: every night the woman would set the table for the spirits and dish them up plenty of food in order to gain protection for her business. The woman only abandoned this ritual after Saint Germain convinced her that these are bad spirits that take advantage of people who believe only half-heartedly in the Christian God (Der sielen troest 1484, a8v; Schmitt 1959, p. 17, 11 . 3-23). The faithful are instructed to let their love for God not only prevail above the love for material things - which are only too easily venerated as idols—-but also above the love for their housemates and family members: their parents, wives, husbands, children, friends and relatives (Der sielen troest 1484, b3v; Schmitt 1959, p. 24, 11. 17-27).

In the second chapter, the father tells the reader not to let his mouth get accustomed to swearing in vain as did a knight who cursed by the Lord's eyes in particular. While playing a board game his eyes fell out of their sockets and he stayed blind for the rest of his days (Der sielen troest 1484, c1v; Schmitt 1959, p. 38, 11. 1-15). Equal dangers lie in swearing an oath one cannot keep and in taunting saints, and Mary in particular (Der sielen troest 1484, c2r-c4r; Schmitt 1959, p. 38, 1. 15-p. 44, 1. 28). Jesus' name should be kept in high regard, spoken and heard with great pleasure, since it serves as a weapon against all kinds of evil: "Dear child, if you wish to keep the second Commandment so you shall gladly mention the name of our Lord Jesus Christ and gladly hear [his name] mentioned because the name of God is as virgin honey" [[L]ieve kint, wilste dat ander gebot wel houden, soe selste den naem goods ons heren Ihesus Cristus gheern noemen ende gheern horen noemen want die naem goods is als honich seem] (Der sielen troest 1484, c3v-c5v (Der sielen troest); (Schmitt 1959, p. 44, 11. 29-31)).

At the start of the third chapter, the father instructs the child not to work, nor to let your family work on holy days. Moreover, one should not dance, sing or jump, since one who dances on holy days might just as well plough or do other work (Der sielen troest 1484, d7r; Schmitt 1959, p. 69,

7 I cite the Dutch text according to the 1484 edition published in Haarlem by Jacob Bellaert (Der sielen troest 1484), followed by a reference to the relevant passage in Schmitt's edition of the Low German text (Schmitt 1959). Spelling and punctuation of the Dutch text have been modernized. 
11. 1-22). The father encourages the child not to eat or drink to excess, which is always sinful, but even more so on holy days (Der sielen troest 1484, d8r; Schmitt 1959, p. 71, 11. 33-36). Furthermore, one should go to church on feast days, and make up for what one may have neglected during the week. Above all it is important to hear Mass—not only on holy days, but—if possible—on workdays as well (Der sielen troest 1484, d8v; Schmitt 1959, p. 72, 11. 22-27). The latter lesson is supported by an exemplum about young knight Willem whose life is saved because his father taught him to attend Mass daily (Der sielen troest 1484, d8v-e1r; Schmitt 1959, p. 72, 1. 28-p. 74, 1. 2). This suggests that parents should take responsibility for religious education of this sort. As we will see, other texts do indeed elaborate on this matter.

Apart from hearing God's word eagerly, one should also dedicate oneself to a more private devotion on holy days: prayer. Nigel Palmer has already observed that the chapter on the third commandment in particular contains an instruction for prayer that is important for the history of devotion or Frömmigkeistgeschichte (Palmer 1992, cols. 1033-34). Early printers made these directions and the associated prayers and meditations widely available. As with church attendance, holy days may serve to catch up with prayer skipped during the week (Der sielen troest 1484, e3v-e4r; Schmitt 1959, p. 78, 1. 36-p. 79, 1. 2). The most important message is that the chosen prayer is less important than the mental attitude with which it is performed. You should simply choose the prayer that lends you the most fervor:

Lieve kint, wat gebet dat di alre meest innicheit gheeft dat selste alre liefste lesen ende spreken, het si dat Pater Noster ende dat Ave Maria of dat si een ander ghebet. Ende du selste dy immer vlietigen dair toe dattu innichlike ende mit pure herten bedeste, dattu ander lude niet en hinderste, dattu ymmer wat innicheit of wat geestelicheit ende wat sueticheit voelste, want beter is een Pater Noster mit innicheit gesproken dan een heel souter sonder innicheit (Der sielen troest 1484, e3v-e4r; Schmitt 1959, p. 79, 11. 3-12).

[Dear child, whichever prayer lends you the most fervor that you should read and speak preferably, whether it is the Pater Noster and the Ave Maria or [whether] it is another prayer. And you should always apply yourself to pray with inner fervor and with a pure heart, not to disrupt other people, to always feel some fervor or devotion and some sweetness, because it is better to speak one Pater Noster with fervor than an entire Psalter without fervor]

If you read the hours, you should read them slowly and enunciate each word. You should learn to commend your prayer to Our Lord, and say as many prayers as is within your power, sometimes more, sometimes less, depending on the amount of time you have, but always with fervor (Der sielen troest 1484, e4v; Schmitt 1959, p. 80, 1. 30-p. 81, 1. 4). Ideally, you should first pronounce three Pater Nosters in honor of the Holy Trinity. This instruction is followed by brief descriptions of fifteen moments from the life of Christ-from the Annunciation to the Ascension — and the recommendation to pronounce each of the moments together with a Pater Noster and an Ave Maria, or with two or three of these prayers, depending on how much time you have at hand. Should the fifteen moments be too long, then you should omit part of the list and speak five Pater Nosters and Ave Marias to Christ's five wounds, supplemented with whatever you prefer. And if you do not actually pronounce your prayers out loud, you should at least say a Pater Noster to Our Lord "interiorly" (spreken innentlike) (Der sielen troest 1484, e5r; Schmitt 1959, p. 81, 1. 5-p. 82, 1. 6).

Christ's Passion should be the central focus during prayer. Prayers should be prayed in honor of Christ's suffering, with compassion, and seven times a day (during the canonical hours, i.e., vespers, compline, matins, primes, tierce, sext, none) it should be remembered how Christ suffered for us. The Soul's Consolation provides short meditative texts for each of the hours, starting with those in the evening: the washing of feet for vespers; the arrest of Jesus for compline, and so on. While the father confessor narrates the events in third person, the prayers (originally in verse) that follow allow the devotee to repeat the events in direct speech to Christ (Der sielen troest 1484, e5v-e8v; Schmitt 1959, p. 83, 1. 14-p. 90, 1. 31). The author concludes these 'hours' with the following remark: 
Lieve kint, mit desen vij dage ghetiden selste die mertelie ons heren eren. Duncket di dese vij getide te lanc wesen, so wil ic dy een ander leren dat corter is...

[Dear child, with these seven hours you shall honor the agony of Our Lord. Should you deem these seven hours too long, so I shall like to teach you another [prayer] that is shorter ... ]

What follows is a prayer that focuses on Christ's wounds. Another prayer exercise focuses on four moments at which Christ shed bitter tears (Der sielen troest 1484, e8v-f1v; Schmitt 1959, p. 90, 1. 32-p. 95, 1. 3).

Equally elaborate directions for church attendance follow these extensive, yet flexible and pragmatic instructions with regard to prayer. Naturally, this is something that would take place outside of the domestic sphere. This does not mean to say, however, that church attendance is entirely independent from domestic devotion - after all, preparation for church attendance would take place at home. Nevertheless, a brief summary has to suffice here. When you come to church you should not speak or even whisper. When you come to hear Mass, you shall make good use of your time: you shall pray and weep, and never make yourself comfortable but alternate seated, standing, and laying positions, fall to your knees every so often, make the sign of the cross or beat your chest. The author specifies bodily positions for each part of the Mass, provides an interpretation of the hymn Gloria in excelsis Deo, a translations of Te Deum laudamus and Salve Regina, and prayers for certain moments during Mass, for example during the elevation of the consecrated host (Der sielen troest 1484, f1v-f4v; Schmitt 1959, p. 95, 11. 4-7 and p. 95, 1. 18-p. 100,1. 6).

After the instructions for Mass, the author-addressing the audience in the person of the father-returns to the topic of prayer and reminds the child/reader to pray as he has taught him/her, and to speak to Mary after s/he has prayed to Christ. An exemplum about a priest who prayed in remembrance of the seven joys of Mary every day introduces the short expositions and rhymed prayers on these seven joyful moments (Der sielen troest 1484, f4v-g4r; Schmitt 1959, p. 102, 1. 29-p. 120, 1. 25). This section again follows the same structure as the elaboration on the seven hours and the four moments when Christ wept: the prayer verses repeat in direct speech what has been explained and narrated, and the similes and Old Testament prefigurations that have been discussed in prose. The second joy also includes an explanation and translation of the hymn Magnificat anima (Der sielen troest 1484, f5v-f6r; Schmitt 1959, p. 104, 1. 33-p. 105, 1. 15). These seven joys 'introduce' various Marian exempla and miracles that are used to underpin the effectiveness of Marian prayer, not only of the Ave Maria (in Dutch or in Latin, however you may have the most fervor-Duytsche of in Latijn, hoe di meest innicheit hebste), but also of the sequence Ave preclara, which you shall hear gladly or read yourself (Der sielen troest 1484, g4v-g5v; Schmitt 1959, p. 120, 1. 26-p. 125, 1. 27).

The fourth commandment is explained as follows: each child who disobeys or causes grief to his parents commits a mortal sin and kills his or her own soul (Der sielen troest 1484, g6v-g8r; Schmitt 1959, p. 126, 11. 1-11). However, one should not obey his parents in things that go against God's will or follow them in their evil ways (quade dinghen). Moreover, one should always help his parents in their needs and remember that they suffered many a broken night for them (Der sielen troest 1484, g8r-h3r; Schmitt 1959, p. 129, 11. 17-18, p. 132, 11. 35-36, p. 133, 11. 19-20, p. 135, 11. 21-27). In turn, parents should manage their possessions wisely and not give everything to their children so as to not be reduced to beggary (Der sielen troest 1484, h3v; Schmitt 1959, p. 136, 11. 26-30, p. 137, 11. 17-18). It is equally important to help your parents after their death. One of the exempla that supports this statement recounts the story of a woman who, in order to gain material wealth, promised the devil to sleep with priests and other religious persons, to take in poor people and throw them out at night, to chat in church so as to hinder others in their prayer, and never to confess again. Eventually, after her death, her son confesses her sins and does penance for seven years, which frees his mother from the pains of hell. The father advises the child to be as faithful to his own parents' souls as the son (Der sielen troest 1484, h6r-v; Schmitt 1959, p. 142, 1. 25-p. 143, 1. 23).

With good works and a devout life, you should also honor your spiritual father, Jesus Christ (Der sielen troest 1484, h7v; Schmitt 1959, 145, 11. 11-17). Moreover, to honor the image of the cross 
is to honor Christ himself. The crucifix thus plays an important part in the domestic sphere, as we read in the story about a Christian who rented a house for a year and fixed a crucifix to the wall of his room to which he used to pray. When he moves out, he forgets to take the crucifix off the wall, and the new residents, Jews, torture the crucifix until it starts to bleed. When the blood heals their sick, however, they convert to Christianity (Der sielen troest 1484, h8r; Schmitt 1959, p. 146, 1. 13-p. 147, 1. 5). Because of the protective powers of the sign of the cross-demonstrated by a story about a Jew who does not fall prey to the devil because he crossed himself-it is advisable that every Christian, before going to bed in the evening, say his prayers and make the sign of the Cross (Der sielen troest 1484, i2r-v; Schmitt 1959, p. 150, 1. 17-p. 151, 1. 22). Besides, you should honor your heavenly father with the prayer that Christ himself taught his disciples. Here, the father translates the words of the Lord's Prayer into the (Dutch) vernacular, warns never to impede anyone praying a Pater Noster, and reminds the reader to always pray the Lord's Prayer with the greatest possible fervor (Der sielen troest 1484, i3v-i4v; Schmitt 1959, p. 154, 11. 14-24, p. 155, 11. 34-38). A woman, whom the author brings forward because of her exemplary prayer, can scarcely say a single Pater Noster during an entire Mass due to her zealous and meditative way of praying, as she explains herself:

Ic en can niet anders dan dat Pater Noster ende ic spreket in Duytsche. Dat doe ic daer om dat ic dat verstae wat ic bidde. Ende spreke icket in Latijn soe en verstae ickes niet ende soe en wert daer mi gheen innicheit of. [ ... ] als ic dat Pater Noster beghin soe spreec ic aldus: "Vader ons". Soe neem ic dese ij. eerste woerden ende begin te dencken daer op dat die hemelsche god mijn vader wesen wil ende dat ic sijn kint werden mach of ic wil ende ic sijn erfnaem wesen sel. Ende dat mi die hemeslche vader so grote lieft ende trouwen bewesen heeft meer dan ye vader sijn kinde ende dat hi om mi een mensche gheworden is ende om minen wil soe groot armoede geleden heeft [ ... ] ende te lesten leet hi om minen wille den bitteren doot. [ ... ] Als ic dit bedencke soe ghevet mi God bi wilen soe grote innicheyt ende soe grote soeticheit in mijnre herten dat ic een heele misse toe brenghe inden enen woerde "vader mijn". Daerna bedencke ic wat daer nae volget [ ... ] soe bedenc ic alle die woerden die in dat pater noster sijn, so en kan ic onder eenre misse nauwe een pater noster spreken [ ... ] (Der sielen troest 1484, i5r-v; Schmitt 1959, p. 156, 11. 2-35).

[I only know the Pater Noster and I speak it in Dutch. I do that so that I understand what I am praying. And [if] I speak it in Latin, I do not understand it and I do not get any devotion thereof. [ ... ] ] when I start the Pater Noster I speak as follows: "Our Father". And I take these first two words and start to think thereupon that the heavenly God wants to be my father and that I may become his child if I want and be his heir. And that the heavenly father showed such great love and faith, more than a father ever [showed] his child and that he has become a human being because of me and for me has suffered such great poverty [... ] and eventually he suffered the bitter death for me. [ ... ] When I consider this, God at times gives me such great devotion and such great sweetness in my heart that I spend an entire Mass in the only word, "Our Father". Then I recall what comes next [ ... ] in this way I recollect all the words of the Pater Noster and so during a Mass I can barely speak one Pater Noster [ ... ] ]

This description of exemplary prayer is instructive and allows us to form a clearer picture of what the author means with his constant emphasis on fervor: a meditative, and visually oriented form of prayer. This exemplum also prompts the child to inquire about the relationship between the vernacular and the language of the Church and to ask whether the Pater Noster is "as good" (soe goet) in Latin as in Dutch. According to the father, a book is as good in the hands of a child as it is in the hands of a priest, but it is more profitable for the latter. Similarly, the Pater Noster in Latin is as good in a priest's mouth as in the mouth of a layman, but a priest who understands the words may receive more fervor thereof than a layman. Moreover, Jesus did not teach the prayer in Latin, but in the language of the Jewish lands-had he lived in the Low Countries, he would have taught the Pater Noster in Dutch 
(Had hi in duytschen landen gheweest, hi had duytscher tale gheleert). Nevertheless, should you prefer Latin that is fine too (Der sielen troest 1484, i5r; Schmitt 1959, p. 157, 11. 6-27).

The child further interrogates the father: is the Lord's Prayer sufficient, or should one's religious practice also include other prayers? The father draws an analogy with a domestic scene: if you come to the table and you find bread and wine only, you will not die of hunger, but it is not enough to satisfy you. The sustenance of the soul is ardent prayer, and the prayer should be as manifold and colorful as the foodstuffs that you eat. Apart from the Pater Noster you should say "the Ave Maria, the Creed, the Seven Psalms, the Book [=the Hours] of Our Dear Lady and of Our Dear Lord, of his Passion, of the Holy Cross, and of the five holy wounds" (dat Ave Maria ende Credo in deum ende die vij psalm ende den boeck van onser vrouwen ende van onsen lieven heer, van sijnre marteli, van den heylighen cruce ende vanden heilighen vijf wonden) (Der sielen troest 1484, i5r-v, quote on i5v; Schmitt 1959, p. 157, 1. 28-p. 158, 1. 17). The father provides the text of five prayers (to Christ, Mary, your guardian angel, your apostle and all apostles, and for the consolation of all Christians) and instructs the child to pray for the deceased when walking across a graveyard (Der sielen troest 1484, i5v-i7r; Schmitt 1959, p. 158, 1. 18-p. 161, 1. 34).

The fifth commandment not only applies to actual murder, but equally to 'moral' death caused by the tongue: rumors can kill over the distance of more than a hundred miles and take the soul of many a man (Der sielen troest 1484, 13r; Schmitt 1959, p. 188, 11. 27-36). If one is in charge of others, one should guide his subjects and children so that they do not corrupt their souls (Der sielen troest 1484, 14v-15r; Schmitt 1959, p. 191, 1. 33-p. 192, 1. 4). Adultery, the sixth commandment (Ex. 20:14 thou shalt not commit adultery), may not be committed in your home, yard or anywhere on your property (Der sielen troest 1484, 16r; Schmitt 1959, p. 196, 11. 1-13). Living a chaste life also involves overcoming bodily temptations and chastising your body "with hunger and with thirst, with waking and prayer, with uncomfortbale clothes and hard beds, with rods and with scourges" (mit hongher ende mit dorst, mit waken ende mit bidden, mit scerpen clederen, mit herder legheren, mit roeden ende mit gheselen) (Der sielen troest 1484, 17r; Schmitt 1959, p. 198, 11. 18-22). If you want to avoid impurity, you should keep away from the company of women (Der sielen troest 1484, 18r; Schmitt 1959, p. 206, 11. 30-35). Furthermore, the father advises the child to be a manlic man (a valiant man) and not to succumb to a bad woman because she will make you into a fool, the fate that Sardanapalus and Solomon suffered. You may, however, gladly follow the counsel of your good wife (Der sielen troest 1484, m3r-m6v; Schmitt 1959, p. 207, 1. 5-p. 215, 1. 3). The child, now taking on the role of a woman, asks what she can do if she wants to live a chaste life but her husband does not agree. She always has to follow the will of the man and keep a chaste soul-if he does something to which he is not entitled, he will receive what is coming to him, although she shall always reprimand him. If you lead a chaste life-which demands a true battle against temptations and with your own thoughts-your soul will become God's temple and a home for the Holy Ghost (Der sielen troest 1484, m7v-m8r; Schmitt 1959, p. 216, 1. 29-p. 217, 1. 9).

The chapter on the seventh commandment (Ex. 20:15, thou shalt not steal) contains many concrete queries about unjust property, which also affect the home and devout actions. For example, it is forbidden to keep a thief in your home, because that would make you complicit to theft (Der sielen troest 1484, n1v; Schmitt 1959, p. 219, 11. 2-3). The child, again taking the role of a woman, asks whether she may steal from her husband in order to give alms. Of the goods that belong to both her and her husband she may take a little, answers the father, as long as it does not harm her husband or upset him. Only in the event of an emergency-when someone is in danger of dying of starvation-may she break these rules. The same applies for children and servants. Women who actively contribute to the income of the household may give alms more freely than women who do not work (Der sielen troest 1484, n1v; Schmitt 1959, p. 220, 11. 10-29). Interestingly, a child may be stolen by a Christian from a heathen-in war and in peace time--because the Christian does not harm the child's father: he will bring the child to God whereas the heathen would have brought it eternal damnation (Der sielen troest 1484, n2r; Schmitt 1959, p. 221, 11. 22-27). Within the context of the ninth commandment, thou shalt not covet your neighbour's goods, the child asks whether a woman may possess and use goods that her husband has gained unjustly. She may only do so in dire need. If it is unclear which goods have been gained 
unjustly and which have not, then husband and wife should divest themselves of all their possession: it is preferable to go begging from door to door than to have unjust goods. Should the husband not consent, the wife may go to the bishop (Der sielen troest 1484, o3v; Schmitt 1959, p. 241, 1. 8-p. 242, 1. 9). Money or other goods won with gambling should be given away as alms. Gambling is a great sin and those who allow it in their homes sin as well (Der sielen troest 1484, o4v; Schmitt 1959, p. 243, 1. 17-p. 244, 1. 19).

The tenth commandment, thou shalt not covet your neighbour's wife (Ex. 20:17), is said to be equal to the ninth, and first focuses on man's desire for another's wife. The story about King David and Bathsheba is followed by the stories of King Abimelech, Abraham and Sarah, and Isaac and Rebecca (Der sielen troest 1484, p1r-1v; Schmitt 1959, p. 254, 1. 1-p. 257, 1. 16). These Old Testament-exempla are followed by a rather crude and cruel story aimed at women. A knight and his household witness that the wife of the stork who has his nest in their grounds consorts with another male whenever the stork is out in search of food. Usually, the female washes herself in a nearby pond after her lover's visit, but one day her access to the water is obstructed. When her husband notices what she has been up to, he calls for a number of other storks that stab her to death. The author concludes: "This shall be an example to all women" (Dit sel een exempel wesen alle vrouwen) (Der sielen troest 1484, p1v; Schmitt 1959, p. $257,11.17-29)$.

The Soul's Consolation concludes with an elaborate narration of King Alexander, who is portrayed as the epitome of a bad life (Der sielen troest 1484, p2r-p7v; Schmitt 1959, p. 258, 1. 8-p. 271, 1. 31). Here, in this life he did not observe the Ten Commandments, and now he has to obey the devil. A last direct instruction to the child summarizes the goal of the text: keep to the Ten Commandments so you will not end up as Alexander but reach eternal life. Thanks to the activity of early printers, the text's many instructions on how to implement the Ten Commandments into daily life and the household became available as printed words. Many of the issues discussed in The Soul's Consolation were taken up in other works that appeared as printed books in the last quarter of the fifteenth century. The following sections focus first on prayer and meditation and subsequently on family life within the devout home.

\section{Prayer and Meditation}

The Soul's Consolation not only contains an extensive discussion of prayer but also material one could actually use to live up to the instructions: the short meditations and prayers on the (seven hours of the) Passion, the four moments at which Christ shed bitter tears, the seven joys of Mary, a Dutch translation of the Pater Noster and several other texts and prayers to 'spice up' religious practice (see above, Section 2). Other texts that were disseminated in printed form offer many interesting parallels. Discussing the contents of these works yields a more complete picture of what incunabula in Dutch offered readers with regard to instruction and texts, how they functioned and even (potentially) interacted. Dionysius the Carthusian gives identical advice when discussing the third commandment: on holy days one should be fervent in prayer and spend the day with psalms, hymns and spiritual songs (Carthusiensis 1479, 55r-v). The words at the end of his Van den loveliken leven en de staet der echten [On the laudable life and state of marriage] also resonate with The Soul's Consolation's quest for attentive prayer in which less is more and a thorough understanding of the prayer-through the use of the vernacular-is vital:

Ende want beter ende saliger is luttel woerde des gebeets mit verstant ende andacht te spreken dan veel sonder verstant ende andacht. Daer om ist nutter ende oerberliker dat die ongeleerde menschen lesen hoer pater noster ende ander gebeden des ghelijcs in Duutscht dan in Latijn. (Carthusiensis 1479, 115v)

[And because it is better and more blissful to speak a few words of prayer with understanding and attention than many without understanding and attention. Therefore, it is more useful and profitable that uneducated people read their Pater Noster and other prayers as well in Dutch than in Latin.] 
The Tafel des kersteliken levens [Table of Christian life] instructs the reader in five points on how to lead a correct Christian life (Tafel 1478, A2r; edition of the Low German text based on Tafel c. 1475 in Bahlmann 1894, pp. 63-75, see also pp. 19-20z). After he wakes up in the morning, he is to contemplate that God has created him in His image. He should read at least one Pater Noster and one Ave Maria "with fervor of his heart" (wt ynnicheit sijns herten) "on his knees in front of his bed" (op sinen knyen voer sinen bedde), and plan to keep to the Ten Commandments. Additionally, prayer booklets such as Die gulden Litanie vander passien Cristi [The Golden Litany on the Passion of Christ] offer readers "a good blessing that one should say in the morning when one gets up" (Een goede zegheninge die men des morghens segghen sal als men op staet), directed at the Father, the Son and the Holy Spirit (Die gulden Litanie 1492, d7r-v). Afterwards, in church, he should hear Mass devoutly, contemplate Christ's Passion, and read his five wounds with five Pater Nosters and Ave Marias (Tafel 1478, A1r-A1v). Other texts, such as Dionysius' Van den loveliken leven and the Korte lering uit de schrifturen der heiliger leraars [Short teaching from the scriptures of holy teachers], elaborate on behavior in church and stress the importance of a devout, attentive and interiorized experience instead of gaping or walking around and chatting as if one were at the market (Carthusiensis 1479, 115v; Korte lering 1481-1482, h7v-i5r, has chapters on "How you should go to church" (Hoe ghi te kercken selt gaen) and "In church" (Inder kercken), which give similar advise). An interiorized experience of the Mass could be achieved using one of the many printed booklets that encourage readers to meditate on the Passion by offering so-called allegorical-rememorative explanations of the ritual (e.g., Boecxken 1479; see below Section 4; Dlabačová 2019).

At noon, before lunch, according to the Tafel, a good Christian should thank the Lord, and read, consciously and with devotion, a benediction or a Pater Noster. After the meal, he should say grace, give alms and, should it be within his powers, he should welcome a poor man once a week at his table (Tafel 1478, A1v). The fact that Dionysius enumerates the failure to say grace before and after the meal as one of the points one might want to address during confession shows that this was indeed considered standard practice (Carthusiensis 1479, 86v). Before going to bed he should reiterate his actions during the day, repent any sins and do penance according to the advice of his father confessor. When going to sleep he should first read three Ave Marias, again on his knees, pray to Our Lady to keep him safe from the devil's temptations during the night, and commend himself to the Lord, Mary, and to his Holy Angel and Apostle. This shall make him sleep peacefully and, in the morning, wake up with ever more commitment to honor God (Tafel 1478, A2r). The materials one would need to conform to the given instructions-and more-are also provided. There are translations into Dutch of the Pater Noster, the Ave Maria, and the Creed. In the next section—referred to as the register (dat register) - the author lists, amongst others, the external and internal senses, the four cardinal virtues, the Four Last Things, the seven deadly sins, the seven works of mercy, the seven gifts of the Holy Ghost, the seven sacraments, and the Ten Commandments (Tafel 1478, A2r-v).

Dionysius the Carthusian in his Van den loveliken leven gives very similar advice for (married) lay people in search of a devout life: they should pray every morning, and moreover, everything one does during the day should be commended to God. Therefore, it is advisable to pray or contemplate before going off to do bodily work, and once at work you should often direct your heart to God with short prayers and devout thoughts. Worldly work done in honor of God is virtuous and can earn eternal life: while a good, devout priest earns eternal life with reading his hours, farmers, merchants, artisans, lawyers and officers earn it through their profession as long as they work out of love for God. Before going to bed all Christians should first examine their conscience and how they fared that day (Carthusiensis 1479, 69v-71r). The anonymous Glose ofte expositie opten psalm Miserere [Gloss or Exposition on the Psalm Miserere] (the third Penitential Psalm) advises to let your consciousness be a book in which you note down all your sins during the day. At night, when you go to sleep and no one bothers you, you may open the book and read all sins you have committed with words, deeds, and thoughts (Glose 1491, b2v-b3r). King David is said to have washed off his sins with tears at night (Glose 1491, a4r). According to Dionysius, after the examination, one should say some prayers, 
especially the Lord's Prayer and Ave Maria, make the sign of the Cross, entrust oneself to God and enter the bed. Once in bed one should contemplate blissful matters, especially Christ's Passion, until one falls asleep (Carthusiensis 1479, 69v-71r). Moreover, those who can afford to do so should also go to vespers and compline in the afternoon and in their bedroom they should focus on God in their prayer or contemplation, "and study something good if they are educated" (ende wat goets studeren is dat si gheleert sijn). The remark that this applies more to the rich and noble than to poor and working people (Hier toe sijn die rijcke ende edele luden meer verbonden dan die armen ende arbeyts luden) points to differences in (the demands for) devotional practices between social classes (Carthusiensis 1479, 73v).

Both the Tafel and Dionysius prefer the bedroom as the place of prayer. Quoting from Matthew 6:1-6, Dionysius stresses that prayer should take place in the bedroom, with the door closed (cf. on the bedroom in Jewish prayer practice: Kohn 2019, Section 4): Christ advised not to pray in public because there one might seek praise from others, and because a secret, quiet place encourages devotion. This does not mean that one cannot pray elsewhere. When praying in church or somewhere else where others are present, you should not pray or sigh loudly, beat your chest more than others, or show any sign whatsoever of exceptional devotion so as not to unsettle others' prayer and resemble the hypocrites (Carthusiensis 1479, 39v). Good Christians should not only pray for themselves, but also for everyone, because one who prays for everyone benefits from the profits of everyone's prayer. Therefore, according to Dionysius, all true Christians should pray daily for the unity, peace, and reformation of the Church (Hier om sel alle waer kersten mensche alle dage bidden om eendrachticheit ende vrede ende der reformacien der heyligher kerken) (Carthusiensis 1479, 68v-69r, quote on 69r).

A one-quire leaflet that might have been useful in accomplishing the daily examination of the consciousness and subsequent atonement that both the Tafel and Dionysius mention, is the Lering van berouw en vergiffenis van zonden [Teaching on repentance and forgiveness of sins]. This text instructs the reader to go into an appropriate place, either in church or at home, to consider ten or twelve of your sins that burden your heart the most, and then to "think in your heart or speak as follows" (peysen metter herten ofte spreken soe hier na volghet) (Lering 1491-1492, a1r). What follows is a prayer script that starts with the formula "O gentle Lord Jesus Christ, you know that I have committed horrible and ugly sins with my evil will in such and such place and at such and such time with such and such persons". In the remainder of the text, the votary asks repeatedly for forgiveness while expressing his regret, considering aspects of Christ's life, and expressing his intention to better his ways (Lering 1491-1492, a1r-a3v). This text was also incorporated at the end of the edition of the Exposition on the Psalm Miserere, which, by example of King David, aims to bring readers to knowledge of and penance for their sins. It includes a special exposition of the psalm Miserere in the form of a prayer, which one should read once a day-or two or three times or at least once a week (of twe of drywerf of ten minsten eens ter weken)-in order to receive forgiveness for your sins (Glose 1491, d1r-e1r; Lering 1491-1492, e4r-e8v). Printed booklets such as these may well have found their way to late fifteenth-century bedrooms and assisted readers in their evening rituals. To find out more about repentance, one could consult a text such as Van den seven sacramenten [On the seven sacraments] where one would find an answer to questions such as "What is repentance?" and "What brings a person to repentance?" (Van den Seven Sacramenten 1484, a5r-a7v).

After a section that focuses on the role of parents in the upbringing of their children (see below, Section 4), the text of the Tafel comes to a close (Hier eyndet die tafel des kersteliken levens). The printer, Gerard Leeu (d. 1492), or the editor of the text, however, added a poem in praise of the Holy Sacrament, the Lof van den Heiligen Sacrament. The poem was written by the famous Bruges rhetorician Anthonis de Roovere, who composed it back in 1456-57. Thus, the edition combines a text previously published in Cologne around 1475 (the Tafel) and a poetic reflection on the nature of the Sacrament. In view of the importance of De Roovere as a famous poet in his own right, this final part has attracted the attention of literary scholars, who write about the publication in terms of collaboration between the poet and Gerard Leeu (Oosterman 2018b, p. 160). Although it is true that Leeu had a connection with Bruges, it seems difficult to imagine that De Roovere would have advocated for the publication of his most 
famous work — by then a more than twenty-year-old, widely disseminated classic—as an anonymous addendum to a catechetical work transferred into Dutch from Low German. Together with the Tafel the poem would have functioned as a prayer, likely in preparation of the Mass, and could be read in church or at home. As such, Leeu's edition is an excellent example of how incunabula further bridged the distance between the private domestic sphere and the Church and could bring home devotions and devotional texts such as prayers in the most literal sense. De Roovere's praise of the Sacrament was also placed on the wall of a church (in handwritten form) and thus functioned within the public space (Mareel 2017, pp. 237-38 and pp. 243-48). Incunables such as the Tafel were intermediaries in this sense, not only between the clergy (priests) and lay people, but also between public space and people's individual homes.

Leeu published another set of poems attributed to de Roovere on the History of Salvation, the life of Christ, and the Four Last Things (Death, Judgement, Hell, Heaven)—not as a book, but as single sheets that could be cut up and either hung on the wall or held in the hand (Geirnaert and Lievens 2018; Oosterman 2018a and Oosterman 2017). These poems were likely used as decoration in the home while also functioning as objects of devotion, giving residents the opportunity to engage in prayer and meditation on Christ's life (cf. Mareel 2017 and Areford 2010, pp. 1-14). The images in the form of woodcuts that accompany each prayer would have enhanced devotion and the visual aspect of prayer, a characteristic of prayer and meditation emphasized in the description of the ideal prayer in for example The Soul's Consolation (see above, Section 2). Leeu's Rosarium Beatae Virginis Mariae editions reflect briefly on the function of woodcut images in relation to the articles or prayers that comprise the Rosary: "Each article has its own image, depicted in front of the eyes, in order that it arouses ever-new devotion in anyone looking at the image and reading the article" (Habet autem quisque articulus suam propriam figuram ante oculos depictam, ut ipsa nouam semper atque nouam figuram uidenti et articulum legenti afferat deuotionem) (Rosarium 1487, a5v-a6r; Dlabačová 2020b). The woodcuts Leeu used to illustrate De Roovere's poems would have had a similar function in the meditative practice of the votary. Gerard Leeu used the same woodcuts in a number of works that facilitated a daily meditation and prayer on Christ's life and the Four Last Things, one of which (the Devout Hours on the Life and Passion of Jesus Christ) its author explicitly directed at lay people juggling work and attention to their spiritual life and religious practice. He 'reinvented' the Book of Hours for those who "who live in the world and participate in the active life [and] spend a lot of time bustling about their livelihood, trade or business, for which reason they do not have the time or the strength to keep the seven [canonical] hours" (Dlabačová 2017, paragraph 8; Dlabačová 2020a).

The centrality of Christ's Passion and the Four Last Things to daily (domestic) devotion is well illustrated by the last chapter of Dionysius' Van den loveliken leven, where he states that all Christians should contemplate Christ's Passion once a day. Furthermore, every Christian should daily "weigh and notice how insecure, deceptive and short this live is" (te wegen ende te merken hoe onsekerlijc bedriegelic ende cort dit leven is), how after death he will be judged by God, how "intolerable and most heavy the pains of hell are" (hoe onverdrachlic ende alre swaerste die pyne der hellen sijn), and contemplate "how indescribable the beatitude and glory of the saints in the realm of the heavens is" (hoe onspredelic dat is die salicheyt ende die glorie der heylighen inden rijke der hemelen) (Carthusiensis 1479, 109r-v). Despite the claim that the heavenly joys are indescribable, a brief description of heaven follows, and short descriptions are given of the Passion and the other Last Things. Still, a book such as the already mentioned Devout Hours or a copy of Die vier uterste [The Four Last Things], which Leeu first published in 1477, would facilitate more in-depth meditations for readers who wanted to follow Dionysius' advice (Die vier Uterste 1477; Devout Hours 1482-1483).

Another work that stresses the importance of books with meditative prayers on Christ's life is the so-called Spiegel des kersten gheloefs, written around the middle of the fifteenth century. Leeu finished printing the text on 1 September 1478, only two weeks after he published the Tafel (Spiegel 1478). Like the Tafel, the Spiegel was previously published in Low German in Cologne by Johann Koelhoff the Elder (Spiegel c. 1477). The text is also known under the title Fundament van der kerstenre gheloven and based 
on sources such as the Compendium theologicae veritatis by Hugo Ripelin of Straatsburg (1210-1270) (Pansters 2007, pp. 99-101). It contains information similar to the Tafel, especially its so-called register (Spiegel 1478, a4r). In the Spiegel, many of the lists are expanded with explanations of each point, as is for example the case with the Creed in Dutch. When discussing the fourth article-the article that relates to Christ's Passion, "I believe that Jesus Christ the Son of God suffered torture from the Jews under Pilate" - it is said that "this point brings before our eyes the Passion and the suffering, and the bitter death" of Our Lord "so that we will always carry that death in our hearts and thank, and praise, and love him for that. If you shed tears while meditating on Christ's suffering, that is a good sign and those tears are salvific" (Spiegel 1478, k3r).

The printer, Gerard Leeu, may well have intended the editions of the Tafel and the Spiegel to be read together-the texts complement each other-and apparently readers did follow this suggestion: two extant copies of both editions were originally bound together (London, British Library, IA.47309 and The Hague, Museum Meermanno Westreenianum, $001 \mathrm{E}$ 049). While the latter Sammelband belonged to a female religious community in Utrecht, the booklets with the Tafel themselves might well have played a role in domestic devotion just as the illustrated meditative prayers mentioned above. The short prologue on the first page tells (potential) buyers that this text encompasses all that a good Christian should know, and all good Christians should therefore have a copy in their homes for themselves, for their children, and members of their household (Tafel 1478, A1r).

A translation with extensive instructions for meditation to accompany each verse of the Lord's Prayer, not unlike the exemplary prayer of the woman who could barely read a single Pater Noster during Mass discussed in The Soul's Consolation, is included in the first chapters of the Boecxken van der officie ofte dienst der missen [Booklet on the office or the service of the Mass] (first published by Leeu on 20 July 1479). These chapters were later incorporated into the Korte lering, which later still was published as the first part of the so-called Spiegel der volcomenheit, not to be confused with Hendrik Herp's Spieghel der volcomenheit (Boecxken 1479; Spiegel 1488). As in The Soul's Consolation a thorough understanding of the meaning of the Lord's Prayer is paramount: only once one has memorized the meaning of the Pater Noster may he read the prayer "after the letter" and fully appreciate it with ardent desire (Korte lering 1481-1482, h4v). The later, extended text (Korte lering and Spiegel der volcomenheit) starts with an exercise on the life of Christ for the seven Hours. There is also a section on what one should read (Vanden daghelicsen lesen [On daily reading]). Although according to the text no general rule can be set for religious reading, since people have different needs and schedules, and it is always advisable to read the Short Hours of the Cross, each hour at the correct time, supplemented with a Pater Noster with considerations on the event of the Passion specific for that hour (Korte lering 1481-1482, g6v; similar reading instructions are given in a text written for a lay woman and transmitted in manuscript only: De Jong 2018). Those unable to read the Short Hours of the Cross can stick to seven Pater Nosters "with remembrance of the Passion" (met ghehoechnis der Passien). However, to make the most of one's religious reading, it is paramount to consult a smart, discerning father confessor for personal, customized advice (Korte lering 1481-1482, g6v-g7r).

The importance of a good father confessor is also recommended in the Twispraec der creaturen [Dialogue of creatures], a Dutch translation of the Dialogus creaturarum. This collection of fables is believed to have been written in northern Italy towards the end of the fourteenth century (Gheraert 2015). Although the prologue points to preachers first when discussing the intended audience, lay readers are not excluded:

Hier om is dit yeghenwoordighe boec nut ende profitelic allen predikers ende allen anderen goeden verstandighen menschen yeghen die verdrietlicheyt des herten der gheenre diet horen ofte lesen. Op dat also ouermits genoechlicheyt der soeter materien dye herten der simpelre menschen getoghen mochten warden tot hogher dinghen in doechden te soeken ende te verstaen (Gheraert 2015, a2r)

[Therefore, this present book is useful and profitable for preachers and all other good, capable people against the sadness of the heart of those who hear or read it. So that through the 
pleasantness of the sweet material the hearts of the simple people may be drawn to search for and understand higher things in virtues.]

In one of the stories recounted by the author, a monkey seeks a cure for her sick cub. She only finds it after a visit to the skillful Master Macer, the master of all herbs, who fixes a medicine from the roots of the plantain ${ }^{8}$. The moralization tells readers to proceed in the same way when seeking their soul's salvation: they should turn to a learned and experienced priest and father confessor who can provide customized medicine (Gheraert 2015, e4v-e5r). In his Der zondaren troost of Spiegel der conscientien [The Sinner's Consolation or Mirror of Conscience], the Franciscan Observant Johannes of Reimerswael compares the soul to the body in order to explain to the "simple, uneducated and good Christians" (simpel ongeleerde ende goede kerstene menschen) how sin corrupts the soul. Moreover, since the soul is more precious than the body one should care more about choosing a 'Master of the Soul' than a good physician (Reimerswael 1492, b3r-v and g6r).

However important religious reading, prayer and contemplation may be, it is nevertheless essential to relax every now and then. In the words of Dionysius: "Just as man cannot always do bodily work, so he cannot always be in spiritual exercise" (Ghelikerwijs als die mensche niet en mach stadelijck lichamelijck arbeyt doen, alsoe en mach hi niet altoos in gheesteliker oefeninghe wesen) (Carthusiensis $1479,98 \mathrm{v}$ ). To provide the soul with rest, she must be entertained with honorable and moderate games. The same thoughts are expressed in the prologue of the Twispraec der creaturen where the story of John the Evangelist is recounted: just as the bow of a hunter would be weakened by bending it constantly, so man has to withdraw from contemplation every now and then in order to reach new heights with regained strength (Gheraert 2015, a2r).

\section{Family Life in a Devout Home}

All of the religious exercises discussed in the previous section and disseminated in printed form in the late fifteenth century were meant to secure the soul's salvation and to-as the father tells the child in The Soul's Consolation - prepare the soul as a temple for God (see above, Section 2). In the Der zondaren troost, written in 1492 and published by Leeu within a week after completion, Johannes of Reimerswael writes about the "house of our soul" (huys onser sielen) which should be made free of all deadly sins (Reimerswael 1492, n5r) ${ }^{9}$. He describes the soul as a home with three rooms (memory, intellect, and will) (Reimerswael 1492, o5r). To let the reader fathom how profound the purification of the soul should be, the Boec van der biechten [Book on Confession], published together with a text by the same author as On the Seven Sacraments (see n. 11), encourages readers to think how sedulously they would prepare their home if a king or bishop were to visit: they would clean so diligently that the eyes of the high ranking individual would not meet anything that could displease them (Spiegel 1480, aa1r). In order to prepare the soul for God, then, one should act as if cleaning the house: "You should do as one who sweeps his house: he searches around all corners and whatever impurity he finds therein he wipes it all out." (Du sulste doen ghelikerwijs als een die sijn huus vaghet: die soect alle die winckelen omme ende wat hij onreyns vindet daer in, dat vaghet hi al wt) (Spiegel 1480, aa1v).

Just as God's spiritual home, i.e., the soul, the actual physical home should indeed also be kept pure and free of sin. Several early printed books in Dutch show that the inner and outer home converge. Gambling and adultery have no place in a devout home, nor should you provide shelter to criminals (Der sielen troest 1484, 16r, $\mathrm{n} 1 \mathrm{v}$ and $\mathrm{o} 4 \mathrm{v}$, see above, Section 2). Pilgrims and the poor, on the other hand, should be given refuge in a devout home. The father or mother should prepare a sleeping place for them in an appropriate location of the home (Carthusiensis 1479, 68r). Furthermore, a devout home should be free of magic. The Soul's Consolation advised against keeping books on magic in your

8 The name likely refers to Macer Floridus, also called De viribus herbarum, an eleventh-century didactic poem and one of the standard works on herbal medicine in medieval Europe.

9 On the soul or heart as a home that should be prepared for God see (Falkenburg 2001 and Klinkenberg 2007). 
home. Similarly, Dionysius the Carthusian, in the discussion of the Ten Commandments in his Van den loveliken leven, advises against the use of texts for magical purposes. Those who seek advice from fortune-tellers who then help them "with apples in which has been written, and with notes to hang around the neck, with odd magical scripture" (mit appelen der in gescreuen is, ende met briefkens anden hals te hangen, mit vreemden carecteren), act against the first commandment (Carthusiensis 1479, 51r). On the Seven Sacraments lists five years of penance for those who mark their home with signs of magic or sorcery (Van den Seven Sacramenten 1484, d8v).

On the other hand, (printed and handwritten) books that contained texts that would assist the faithful in preparing their soul as a home for God were welcomed into the physical household and many of the editions discussed here would have functioned as domestic devotional objects. The walls and furnishings of the family home could serve various devotional functions: they could support printed prayers and images such as the ones printed by Leeu, a crucifix, but the name of Jesus would also inspire a devout home. Various media complemented each other when it came to fifteenth-century domestic devotion, and the printed book played an increasingly important part in it. Again, the contents of these works give a good impression of the kind of instructions made available in print. Dionysius ends his discussion of the Ten Commandments with remarks adopted from Deuteronomy (11:18-20): "The words of the Lord shall be in your heart and you shall tell them to your children and you shall remember them when you sit at home ... and you shall write them in a book and on the door of your home" (Die woerden der heren sellen wesen in dijnre herten ende du selstese vertellen in dinen kinderen ende seltese ghedencken sittende in dinen huse ... Ende du selste scriuen in een boeck, ende inden doeren dijns huses) (Carthusiensis 1479, 64r-v). Similarly, in Vander kersten ewe [On Christian Law], published in print as Spieghel ofte reghel der kersten ghelove [Mirror or rule of Christian faith], readers are advised to paint the sweet name of Jesus in the places of their home where they come most often, because Jesus' name is powerful enough to protect all world (Bange 2000, p. 93; Dlabačová 2014, p. 90). The Soul's Consolation already mentioned this quality of the Lord's name and advised to speak and hear it often. At the end of one of the meditative lives of Christ first published by Gerard Leeu we find a song "on the most sweet name Jesus Jesus Jesus" - a vernacularization of the hymn Ihesu dulcis memoria - preceded by a woodcut of the IHS-monogram (Tboeck 1487, oo4v-oo6r; on this edition see Dlabačová 2008, pp. $330-46)^{10}$. A prayer on Jesus' name at the end of the Devout Hours, to be said everyday together with the Creed and accompanied by a woodcut of the Christ child, would ensure a devotee's daily 'dosage' (Devout Hours 1482-1483, t6v-t7v).

A devout home should also be a place of learning and the man should lead intellectually: if a woman wants to know something, she should ask her husband at home. If he does not know the answer, it should be he who consults prelates or intellectuals (Carthusiensis 1479, 14r-v). The man is the head of the 'house family' and he is in charge of the household, finances, the education of the children, their chastisement, servants, the marriage of daughters, and so on. However, the day-to-day life at home is mainly the domain of the wife (Carthusiensis 1479, 19v-20r). As Augustine already argued, the father should take on the role of the bishop of the home and be more virtuous than everyone else in the house so as to set an example (Carthusiensis 1479, 31r-v, cf. 48v).

Both parents moreover have to take care of the spiritual well-being of their children, and try to guide servants to focus on eternal life as well (Der sielen troest 1484, 14v-5r; Schmitt 1959, p. 191, 1. 33-p. 192, 1. 4; Carthusiensis 1479, 32r). Children should get to know God from an early age and learn how to love and honor him. If they can afford it, parents should not hesitate to send their children to school, at least until they have learned the Pater Noster and the Ave Maria, the articles of the faith and to read and write in Dutch - a type of 'pragmatic literacy' oriented towards a basic knowledge of Christian religion (Parkes 1991; cf. Driver 1989, p. 235). Ideally, however, they should stay in school until they

10 See Lutton 2011 on the (vernacular) cult of the Holy Name of Jesus in England, which seems to have intersections with the Dutch situation. 
have mastered Latin so that they can understand what is being sung in church and can even assist at Mass. Unfortunately, many parents, especially in rural areas, do not provide their children with such an education and thus do not lead them to good morals (Carthusiensis 1479, 24r-24v).

In The Soul's Consolation, we already saw that a father saved his son's life by teaching him to attend Mass daily. The religious instruction of children within a devout household is a recurring topic in the earliest religious texts printed in Dutch. A section directed at parents and describing their responsibility in the Christian upbringing of their children is also included in the Tafel des kersteliken levens. Parents should instruct their offspring to offer their innocence and purity to God, together with the innocents massacred by Herod. Children should be taught the Pater Noster, Ave Maria, the Twelve Articles of the Creed, the Ten Commandments, and everything explained previously in the Tafel and its 'register' (Tafel 1478, A2v). Furthermore, they should be instructed on how to honor their apostle, their holy angel and other saints. They should learn how to bless themselves at night and in the morning, and always enter or leave with the sign of the Cross. Furthermore, they should be taught how to pray in the evening and morning on their knees in front of their bed, how to read their benediction and grace according to custom and fervently, to be austere with regard to food and drink, and also in chatting. They should not gossip and destroy other people's reputation-a topic elaborately discussed in The Soul's Consolation - and keep the home free from evil by not bringing new rumors to their home. If one does not teach this to children from their early youth, they will resemble old dogs that are difficult to tame (Tafel 1478, A3r-v). Parents should give a good example by living a virtuous life, punish their children when necessary, and ensure a good education at the school with the best master of an undisputed reputation (Tafel 1478, A3v-A4r).

On the Seven Sacraments also reminds its readers that parents are obligated to teach their children - or have them taught—in the holy faith, lead them to church and chastise them for their bad habits (Van den Seven Sacramenten 1484, h6v). Marriage has two aims: to create offspring and to avoid sin. Even though, as we have seen before, magic had no place in (the bookcase of) a devout household, the anonymous author of On the Seven Sacraments discusses complications in one of marriage's main aims: the possibility that the husband is made infertile through sorcery or herbs. To remedy such problems, according to this text Albert the Great advises the husband to get hold of his wife's shirt and to pee at once both through the neckband and the left sleeve (Van den Seven Sacramenten 1484, k4r-v).

A good, Christian upbringing naturally starts with the sacrament of baptism. On the Seven Sacraments, a dialogic text not previously transmitted in manuscript and probably created especially for the printing press, discusses this sacrament that was so strongly connected to procreation, one of the main aims of marriage. The author seeks to familiarize non-Latinate readers with the seven sacraments ${ }^{11}$. Many of his instructions pertain to the domestic sphere and appear to empower lay people to transfer the religious ritual not only into their own mother tongue, the Dutch vernacular, but also into their own family home. The author's remark that he asks one of his questions (i.e., how should a priest behave when he hears confession?) "for the benefit of the simple priests who are not lawyers so that they may be informed a little about this" (om der simpelre priesteren willen die welcke gheen iuristen en sijn dat sy doch hier inne wat gheinformeert moghen wesen), however, reveals that his work was at least partially aimed at a priestly readership (Van den Seven Sacramenten 1484, b7v, cf. also c4v).

According to On the seven sacraments, in case of an emergency, baptism can be performed by any person—a woman as well as a man, father or mother (soe wel wijf als man, vader of moeder) —as long as it is done in the way prescribed by the Holy Church (Van den Seven Sacramenten 1484, a1v). The author discusses the Dutch words that one should use and addresses the difference with the Latin original, which has no need for a personal pronoun: "In Latin the baptizer may say: 'baptiso te in nomine patris et cetera', which in our Dutch language would not sound well. Therefore, it is the best that one says:

11 The author came from Holland; see Van den seven sacramenten 1484, 12r, where he writes that this not the custom there. He also wrote the Spiegel des eeuwigen levens, first published in Delft in 1480 (Spiegel 1480). See (Warnar 2019, pp. 494-500). $\rightarrow$ if everything is bracketed this should be too probably (please remove this comment) 
'I baptize you et cetera'" (In Latijn soe soude den doper wel moghen segghen: "baptiso te in nomine patris et cetera", twelcke nae onsen Duytsche niet wel luden en soude. Daerom so ist sekerste dat men segghe "Ick dope di et ceterea") (Van den Seven Sacramenten 1484, a2r). In case a woman is in labor and there is fear for the child's life, the midwife should baptize the child. Only later should the child be brought to church where-if needed-the priest may rectify what failed at home (Van den Seven Sacramenten 1484, a2v). The question whether baptism is legitimate when done 'in jest or joke' (in boerten ende in iocke) seems to point to the performance of religious ritual in a playful or carnivalesque atmosphere (Van den Seven Sacramenten 1484, a3r).

About the compatibility of marriage and a devout, pious lifestyle, one could read more in Dionysius the Carthusian's De laudabili vita coniugatorum, translated into Dutch as Van den loveliken leven en de staet der echten and published by Leeu on 26 July 1479 in Gouda. Written from a male perspective, the text discusses the conduct towards the wife and family, but also offers an explanation of the Ten Commandments, advice about confession, speaking, gambling, and so on. "Learned men" (notabele gheleerden) as well as male acquaintances who live a married life have often asked Dionysius to put pen to paper and write about these matters (Carthusiensis 1479, 2v-3r).

Marriage brings many challenges to a devout, Christian life and home. Some women make their husbands' lives difficult by complaining even at night about how other women have more beautiful clothes and jewels and stand in high regard. They question their husband's behavior: "why did you look in such a friendly manner at that woman? What did you have to discuss with that virgin?" (Carthusiensis 1479, 6v: Waer om saecht ghi dat wijf so vriendeliken an? Wat haddi te spreken met dyer maghet?). In general, marriage makes it difficult to focus on fervent prayer, holy thoughts, and contemplation because it distracts the heart-the lust of the flesh makes the heart unable to care for godly things (Carthusiensis 1479, 10r).

According to Dionysius, it is better to die without children than to leave behind bad children (bose kinderen). As in the Tafel, good Christian parents should reprimand their children whenever they see anything bad in their behavior: they should keep measure in food and drink, sleeping, and in the way they dress (Carthusiensis 1479, 26r-27v). And it is not only children who should keep measure in these matters: all Christian people should beware of food and drink that is too good and beds that are too soft, since opulence darkens the heart and makes the senses blunt (Carthusiensis 1479, 71v-73v). Drinking, especially outside of lunch and dinner, should be avoided, since drunkenness breaks the soul. To bring the message home, Dionysius quotes from Ambrose: the drunk who devours wine will be devoured by it (Carthusiensis 1479, 74v-75v). As to fashion: just as religious people wear the habit of their order, so should all Christians who follow Christ's law wear clothes that show their meekness (Carthusiensis 1479, 77r-v). When discussing the last three Commandments, Dionysius expresses his annoyance at a specific kind of fashion. People tend to wear a cloak (heuke) directly over an undershirt (wamboeys) that is half open on one side which reveals the loins (Carthusiensis 1479, 62r-v). However, both women and men are allowed to make themselves beautiful within reasonable measure in order to keep their partner from going off with someone else (Carthusiensis 1479, 13v). Further, children should be kept from dishonorable dancing and from all forbidden games, especially gambling and tournaments. Girls should especially be kept off the streets and busy so that they do not get the chance to gossip or cast their eyes on men. The example of emperor Octavian who kept his daughters spinning and weaving serves to make a point about textile labors as an important part of a devout household (Carthusiensis 1479, 26r-27v; Dlabačová 2018 on printed texts that offer meditations on Christ's Passion for during spinning and weaving).

\section{Conclusions}

The distinction some scholars make between the period until 1500 as an age in which religious knowledge was "learned over a lifetime-through acts, images, architecture, song, sound, sight, smell, and touch" - and the sixteenth century as an era in which foundational teachings became printed words (Wandel 2016, p. 7, n. 17) does not do justice to late medieval religious developments, book 
production and fifteenth-century printing in particular. The changes that occurred appear to be much more gradual, and a discussion of the contents of a small sample of incunabula shows that the two periods display more overlap with regard to written religious instruction and domestic devotion than scholars acknowledge. Many fifteenth-century believers would have seen 'basic' texts such as the Lord's Prayer or the Creed as printed words on a page. The early 'catechetical' works discussed here paved the way for developments in the sixteenth century: printers such as Gerard Leeu and his contemporaries accustomed Christians to the use of printed books for personal and practical religious instruction and knowledge. Although it might be true that "no text, singularly or in aggregate, was definitive of being 'a Christian'" (Wandel 2016, p. 14), many texts did try to define a 'good Christian'. In this sense, the decades before the Reformation were indeed a "dawn of the Reformation" rather than an "eve of the Reformation"12.

Yet, the material discussed in this essay should prompt us to further reconsider the supposed dichotomy between the medieval and early modern period without viewing fifteenth-century printed books only as predecessors of later, sixteenth-century developments. The first books printed in Dutch offer a wealth of ideals and instructions for prayer, meditation, religious reading, and family life within the devout home. These commercially produced printed pages offer texts that generally do not pertain directly to the Modern Devotion and were often not already disseminated in manuscript. Although a few of the texts specifically addressed at a lay audience were available in manuscript copies, many other ones were never disseminated in manuscript. These printed books would have functioned as devotional objects in lay homes in dialogue with other-printed and handwritten-books containing prayers, exercises and meditations, with (printed) images and objects such as crucifixes or the IHS-monogram painted on the wall. At the same time, there was interplay with public spaces, especially the church to which many of the texts refer and to which readers would have brought their (printed) books. Prayer and meditation in a private space were distinctly different from prayer and meditation in a public space (on the 'consonance or dissonance' between private and public devotion, see, e.g., (Williamson 2013)). Moreover, these early printed books bridged the space between catechetical instruction and the private home, literally bringing home many of the instructions that the clergy would have offered in church and thus increasingly 'textualizing' the lives of the late medieval laity.

Funding: This research was partially funded by the Dutch Research Council (NWO) (Veni-project Leaving a Lasting Impression. The Impact of Incunabula on Late Medieval Spirituality, Religious Practice and Visual Culture in the Low Countries, 2018-2022, grant number 275-30-036) and the essay has been partially researched and written during fellowships at the Herzog August Bibliothek, Wolfenbüttel (2017) and at the Kluge Center, Library of Congress, Washington D.C. (2019).

Acknowledgments: I am indebted to Heather Bamford and Rijcklof Hofman for critically reading and editing the essay.

Conflicts of Interest: The author declares no conflict of interest.

\section{References}

Andersen, Elisabeth. 2016. Religious Devotion and Business. The Pre-Reformation Enterprise of the Lübeck Presses. Ons Geestelijk Erf 87: 200-23.

Areford, David S. 2010. The Viewer and the Printed Image in Late Medieval Europe. Farnham: Ashgate.

Bahlmann, P. 1894. Deutschlands Katholische Katechismen bis zum Ende des Sechzehnten Jahrhunderts. Münster: Druck und Verlag der Regensburgschen Buchhandlung.

Bange, Petty. 1986. Spiegels der Christenen. Zelfreflectie en Ideaalbeeld in Laat-Middeleeuwse Moralistisch-Didactische Traktaten. Nijmegen: K.U., Centrum Voor Middeleeuwse Studies.

12 The term 'dawn of the Reformation' was coined by Heiko Oberman and with regard to printed religious works discussed in (Milway 2000, pp. 137-40). 
Bange, Petty. 2000. Een Handvol Wijsheden. Eenvoudig Geloof in de Vijftiende Eeuw: de Spieghel Ofte Reghel der Kersten Ghelove. Nijmegen: Valkhof Pers.

Bange, Petty. 2007. Moraliteyt Saelt Wesen. Het Laatmiddeleeuwse Moralistisch Discours in de Nederlanden. Hilversum: Verloren.

Boecxken van der Officie Ofte Dienst der Missen. 1479. ISTC no. is00529000. Gouda: Gerard Leeu. Washington: Library of Congress, Rosenwald 467.

Carthusiensis Dionysius. 1479. De Laudabili vita Coniugatorum [Dutch] Van den Loveliken Leven en de Staet der Echten. ISTC no. id00249200. Gouda: Gerard Leeu, The Hague: Royal Library, 169 G 97.

Corbellini, Sabrina, and Margriet Hoogvliet. 2013. Artisans and Religious Reading in Late Medieval Italy and Northern France (ca. 1400-ca. 1520). Journal of Medieval and Early Modern Studies 43: 521-44. [CrossRef]

De Jong, Susanne. 2018. 'Read some good Dutch books.' Laypeople, Books, and Religious Reading in the Late Medieval Domestic Setting. Queeste. Tijdschrift over Middeleeuwse Letterkunde in de Nederlanden 25: 32-54.

Der sielen troest. 1484. Haarlem: Jacob Bellaert. ISTC no. is00361000. The Hague: Royal Library, 168 E 6.

Deschamps, J. 1963. De Middelnederlandse handschriften van de grote en de kleine 'Der sielen troest'. Handelingen Koninklijke Zuidnederlandse Maatschappij voor Taal en Letterkunde en Geschiedenis 17: 111-67.

Deschamps, J. 1972. Middelnederlandse Handschriften uit Europese en Amerikaanse Bibliotheken. Leiden: E.J. Brill.

Horae [Dutch] Devote Getijden van Het Leven Ons Heren. 1482-1483. ISTC no. ih00433130. [Gouda: Gerard Leeu]. San Marino: Calif., Huntington Library, inv. 100989.

Die Gulden Litanie Vander Passien Christi. 1492. ISTC no. il00228900. Antwerp: Gerard Leeu. London: British Library, IA.49852.

Die vier Uterste. 1477. ISTC no. ic00902000. Gouda: Gerard Leeu. Washington: Library of Congress, Rosenwald 462.

Dlabačová, Anna. 2008. Drukken en publieksgroepen. Productie en receptie van gedrukte Middelnederlandse meditatieve Levens van Jezus (ca. 1479-1540). Ons Geestelijk Erf 79: 321-68. [CrossRef]

Dlabačová, Anna. 2014. Literatuur en observantie. De Spieghel der Volcomenheit van Hendrik Herp en de Dynamiek van Laatmiddeleeuwse Tekstverspreiding. Hilversum: Verloren.

Dlabačová, Anna. 2017. Religious Practice and Experimental Book Production: Text and Image in an Alternative Layman's "Book of Hours" in Print and Manuscript. Journal of Historians of Netherlandish Art 9: 2. [CrossRef]

Dlabačová, Anna. 2018. Spinning with Passion. The Distaff as an Object for Contemplative Meditation in Netherlandish Religious Culture. The Medieval Low Countries 5: 177-209. [CrossRef]

Dlabačová, Anna. 2019. Seeing beyond Signs: Allegorical Explanations of the Mass in Medieval Dutch Literature. In Quid est Sacramentum? Visual Representation of Sacred Mysteries in Early Modern Europe, 1400-1470. Edited by Walter Melion, Elizabeth Carson Pastan and Lee Palmer Wandel. Leiden: Brill, pp. 199-226.

Dlabačová, Anna. 2020a. Illustrated Incunabula as Material Objects: The Case of the 'Devout Hours on the Life and Passion of Jesus Christ'. In Inwardness, Individualization, and Religious Agency in the Late Medieval Low Countries. The 'Devotio Moderna' and Beyond. Edited by Rijcklof Hofman, Charles Caspers, Peter Nissen, Mathilde van Dijk and Johan Oosterman. Turnhout: Brepols, pp. 183-224.

Dlabačová, Anna. 2020b. Marian Devotions from a Printer's Perspective. The Rosary, the Seven Sorrows, and Gerard Leeu (d. 1492). In Marian Images in Context: Doctrines, Devotions, and Cults. Edited by James Clifton, Barbara Haeger and Elliott Wise. Leiden: Brill.

Driver, Martha W. 1989. Pictures in Print: Late Fifteenth- and Early Sixteenth-century English Religious Books for Lay Readers. In De Cella in Seculum. Religious and Secular Life and Devotion in Late Medieval England. Edited by Michael G. Sargent. Cambridge: D.S. Brewer, pp. 229-44.

Falkenburg, Reindert. 2001. The Household of the Soul: Conformity in the Merode Triptych. In Early Netherlandish Painting at the Crossroads. A Critical Look at Current Methodologies. Edited by Maryan W. Ainsworth. New York: The Metropolitan Museum of Art, pp. 2-17.

Füssel, Stephan. 2003. Gutenberg and the Impact of Printing. Translated by Douglas Martin. Aldershot: Ashgate.

Geirnaert, Dirk, and Robrecht Lievens. 2018. Van zondeval tot hemel. Staties uit de heilsgeschiedenis: een reeks geillustreerde devotionele strofen van Anthonis de Roovere (Gouda, 1482). Jaarboek De Fonteine 63.

Glose Ofte Expositie Opten Psalm Miserere. 1491. ISTC no. ig00308500. Antwerp: Gerard Leeu. The Hague: Royal Library, 150 F 20 (2).

Goudriaan, Koen. 1992. Een drukker en zijn markt. Gheraert Leeu (Gouda 1477—Antwerpen 1492/3). Madoc 6: 194-205. 
Goudriaan, Koen. 2010. Apostolate and Printing. The Collaciebroeders of Gouda and Their Press. In Between Lay Piety and Academic Theology. Edited by Ulrike Hascher-Burger, August den Hollander and Wim Janse. Leiden: Brill.

Goudriaan, Koen. 2013a. The Devotio Moderna and the Printing Press (ca. 14751-540). Church History and Religious Culture 93: 582-91.

Goudriaan, Koen. 2013b. The Church and the Market: Vernacular Religious Works and the Early Printing Press in the Low Countries, 14771-540. In Cultures of Religious Reading in the Late Middle Ages. Instructing the Soul, Feeding the Spirit, and Awakening the Passion. Edited by Sabrina Corbellini. Turnhout: Brepols, pp. 93-116.

Goudriaan, Koen. 2016. The Franciscans, the Laity and the Printing Press. In Piety in Practice and Print. Essays on the Late Medieval Religious Landscape. Edited by Anna Dlabačová and Ad Tervoort. Hilversum: Verloren, pp. 272-301.

ISTC. Incunabula Short Title Catalogue. London: British Library. Available online: https://data.cerl.org/istc/_search (accessed on 4 December 2019).

Klinkenberg, Emanuel S. 2007. 'Wil diin herte bereeden gheliic eenen huze'. De binnenhuisallegorie in de geestelijke letterkunde. Queeste. Tijdschrift over middeleeuwse letterkunde in de Nederlanden 14: 126-53.

Kock, Thomas. 2002. Die Buchkultur der Devotio Moderna. Handschriftenproduktion, Literaturversorgung und Bibliotheksaufbau im Zeitalter des Medienwechsels, 2nd ed. Frankfurt am Main: Peter Lang.

Kohn, Albert. 2019. Furnishing Piety: Beds in High Medieval Jewish Domestic Devotion. Religions 10: 471. [CrossRef]

Korte Lering uit de Schrifturen der Heiliger Leraars. 1481-1482. ISTC no. il00178300. Gouda: Gerard Leeu. Antwerp: Erfgoedbibliotheek Hendrik Conscience, B 27303 [C25-42 h].

Lering van berouw en vergiffenis van zonden. 1491-1492. ISTC no. il00178600. Antwerp: Gerard Leeu. The Hague: Royal Library, 150 F 17 (2).

Lutton, Rob. 2011. 'Love this Name that is IHC.' Vernacular Prayers, Hymns and Lyrics to the Holy Name of Jesus in Pre-Reformation England. In Vernacularity in England and Wales, c. 1301-1550. Edited by Elisabeth Salter and Helen Wicker. Turnhout: Brepols, pp. 119-45.

Mareel, Samuel. 2017. Tekens aan de wand. Het ophangen, lezen en verwijderen van gebeden en gedichten in katholieke religieuze ruimtes $\left(15^{\mathrm{de}}-16^{\mathrm{de}}\right.$ eeuw). Spiegel der Letteren 59: 231-59.

Mertens, Thom. 1993. Boeken voor de eeuwigheid. Ter inleiding. In Boeken Voor de Eeuwigheid. Middelnederlands Geestelijk Proza. Amsterdam: Prometheus, pp. 8-172.

Milway, Micheal. 2000. Forgotten Best-sellers from the Dawn of the Reformation. In Continuity and Change. The Harvest of Late-Medieval and Reformation History. Essays presented to Heiko A. Oberman on His 70th Birthday. Edited by Robert J. Bast and Andrew C. Gow. Leiden-Boston-Köln: Brill, pp. 113-42.

Murjanoff, Michael. 1964. Zur Überlieferung des Seelentrostes. Beiträge zur Geschichte der deutschen Sprache und Literatur 86: 189-224.

Oosterman, Johan. 2017. Discovering New Media. Anthonis de Roovere and the Early Printing Press. In Medieval Urban Culture. Edited by Andrew Brown and Jan Dumolyn. Turnhout: Brepols, pp. 17-82.

Oosterman, Johan. 2018a. Anthonis de Roovere, Leven en passie ons Heren. In Colard Mansion. Incunabula, Prints and Manuscripts in Medieval Bruges. Edited by Evelien Hauwaerts, Evelien de Wilde and Ludo Vandamme. Gent: Snoeck, pp. 60-61.

Oosterman, Johan. 2018b. Tafel des Kersteliken levens, with: Anthonis de Roovere, Lof van den Heiligen Sacrament. In Colard Mansion. Incunabula, Prints and Manuscripts in Medieval Bruges. Edited by Evelien Hauwaerts, Evelien de Wilde and Ludo Vandamme. Gent: Snoeck, pp. 159-61.

Palmer, Nigel F. 1992. Seelentrost. In Die Deutsche Literatur des Mittelalters. Verfasserlexikon, VL2. Berlin/New York: Walter de Gruyter, vol. 8, cols. 1030-40.

Pansters, Krijn. 2007. De kardinale deugden in de Lage Landen, 1200-1500. Hilversum: Verloren.

Parkes, Malcolm. 1991. The Literacy of the Laity. In Idem, Scribes, Scripts and Readers: Studies in the Communication, Presentation and Dissemination of Medieval Texts. London: Hambledon Press, pp. 275-97.

Pettegree, Andrew. 2015. Brand Luther. 1517, Printing, and the Making of the Reformation. New York: Penguin Press. Pleij, Herman. 1992a. Drukpers, literatuur en geestelijkheid in het laat-middeleeuwse Holland. Madoc 6: 3-19.

Pleij, Herman. 1992b. De betekenis van de beginnende drukpers voor de ontwikkeling van de Nederlandse literatuur in Noord en Zuid. Spektator 21: 227-63. 
Pleij, Herman. 2010. The Printing Press as a Long-Term Revolution. In Books in Transition at the Time of Philip the Fair. Manuscripts and Printed Books in the Late Fifteenth and Early Sixteenth Century Low Countries. Edited by Hanno Wijsman. Turnhout: Brepols, pp. 287-307.

Reimerswael, Johannes. 1492. Der Zondaren Troost of Spiegel der Conscientien. ISTC no. ij00399500. [Antwerp]: Gerard Leeu. The Hague: Royal Library, 150 F 23, Paris: Bibliothèque nationale de France, D-54016.

Rosarium Beatae Virginis Mariae. 1487. ISTC no. ir00318850. Antwerp: [Gerard Leeu]. The Hague: Royal Library, 150 F 9. Schmitt, Margarete. 1959. Der Grosse Seelentrost. Ein niederdeutsches Erbauungsbuch des Vierzehnten Jahrhunderts. Köln/Graz: Böhlau Verlag.

Spiegel des Kersten Gheloefs. 1478. ISTC no. is00672000. Gouda: Gerard Leeu, The Hague: Royal Library, 169 G 94 (1). Spiegel des Eeuwigen Levens and Boec van der Biechten. 1480. ISTC is00671000. Washington: Library of Congress, Rosenwald 478a.

Spiegel der Volcomenheit. 1488. ISTC no. is00677700. Antwerp: Gerard Leeu, The Hague: Royal Library, 1084 D 4. Spiegel des kersten geloven [Low German]. c. 1477. ISTC no. is00671900. [Cologne: Johann Koelhoff the Elder]. The Hague: Royal Library, 170 F 59.

Tafel des Kersteliken Levens. 1478. ISTC no. it00010800. Gouda: Gerard Leeu. The Hague: Royal Library, 169 G 94 (2). Tafel des Kersteliken Levens [Low German] Ene guede Vermaninge en ene Tafel des kerstlyken Levens. c. 1475. ISTC no. it00010830. Cologne: Johann Koelhoff the Elder.

Tboeck vanden leven Jhesu Christi. 1487. ISTC no. il00353000. Antwerp: Gerard Leeu, The Hague: Royal Library, 171 E 39. Troelstra, A. 1901. De Toestand der Catechese in Nederland Gedurende de Vóór-Reformatorische Eeuw. Groningen: Wolters. Troelstra, A. 1903. Stof en Methode der Catechese in Nederland Vóór de Reformatie. Groningen: Wolters.

Gheraert, Leeu. 2015. Dialogus Creaturarum dat is Twispraec der Creaturen. Edited by Hans Rijns. Available online: https://www.dbnl.org/tekst/leeu002diag02_01/leeu002diag02_01_0001.php (accessed on 4 December 2019).

Van den Seven Sacramenten. 1484. ISTC no. is00015000. Gouda: Gerard Leeu, Liège: Bibliothèque Universitaire, XV.C088.

Wandel, Lee Palmer. 2016. Reading Catechisms, Teaching Religion. Leiden-Boston: Brill.

Warnar, Geert. 1993. Biecht, gebod en zonde. Middelnederlandse moraaltheologie voor de wereldlijke leek. In Boeken Voor de Eeuwigheid. Middelnederlands Geestelijk Proza. Edited by Th. Mertens. Amsterdam: Prometheus, pp. 36-51 and 372-80.

Warnar, Geert. 2019. Lady Scripture's Sacred Commitments: Dialogic Understanding in Dutch Religious Literature of the Late Fifteenth Century. In Quid est Sacramentum? Visual Representation of Sacred Mysteries in Early Modern Europe, 1400-1700. Edited by Walter Melion, Elizabeth Carson Pastan and Lee Palmer Wandel. Leiden: Brill, pp. 494-532.

Williamson, Beth. 2013. Sensory Experience in Medieval Devotion: Sound and Vision, Invisibility and Silence. Speculum 88: 1-43. [CrossRef] 